\title{
The socio-economic distribution of health-related occupational stressors among wage-earners in a Post-Fordist labour market
}

by

\author{
Vanroelen $\mathrm{C}^{1}$, Levecque $\mathrm{K}^{2}$, Louckx $\mathrm{F}^{1}$
}

\begin{abstract}
Unequal exposure to occupational stressors is a central pathway towards socio-economic health inequalities in working populations. This paper assesses the differential exposure of such stressors within the population of Flemish wage-earners. Our focus is on differences in gender, age, skill levels, occupational and social class positions.
\end{abstract}

\section{Method}

The analyses are based on the "Flemish Quality of Labour Monitor 2004" (Vlaamse Werkbaarheidsmonitor 2004), a cross-sectional representative sample $(N=11,099)$ of 16 - to 65year-old wage-earners, living in Flanders. The investigated health-related working conditions are: high quantitative, emotional and physical demands, frequent repetitive movements, atypical work schedules, frequent overtime work and schedule changes, low job autonomy, task variation and superior-support, high job insecurity and exposure to bullying. The distribution of the working conditions is assessed by means of standard logistic regression analyses. Also gender specific analyses are performed.

\section{Results}

At least two clusters of health-related occupational stressors can be identified. On the one hand, high physical demands, atypical schedules, low control over the work environment and high job insecurity are more common in manual, unskilled and subordinate workers. On the other hand, high quantitative and emotional demands, as well as schedule unpredictability are characteristic of higher skilled, professional and managerial employees.

\section{Conclusion}

Since little empirical information on the socio-economic distribution of various health-related occupational stressors is available for Flanders, our results are important for obtaining more insight into the pathways linking occupational health risks to socio-economic health inequalities in the Flemish wage-earning population.

\footnotetext{
1 Department of Medical Sociology, Vrije Universiteit Brussel, Brussels, Belgium

2 Research Foundation Flanders \& Department of Sociology, University of Ghent, Ghent, Belgium Correspondence: cvroelen@vub.ac.be
} 


\section{Keywords}

Age distribution, Belgium, gender, health inequality, occupational health, occupational groups, social class, socio-economic factors

\section{Introduction}

In the past forty years, Western capitalist societies have been characterised by profound socio-economic changes, among others in the world of work (1). The theorists of the regulation school have proclaimed a shift between the ideal types of Fordist and Post-Fordist production systems (2). Nowadays Post-Fordist work differs from the Fordist "ideal type" of employment conditions in a number of respects. The Fordist production system was characterised by full, life-time employment, in a bureaucratically organised system of industrial mass production, embedded within the context of a national economy (3). In the Post-Fordist ideal type, the content of work has shifted towards the flexible combination of skills in problem-identifying and -solving processes for the production of material and immaterial goods and services (4), within the context of a more deregulated open world economy and a demographically diversified workforce (1). In the labour process these shifts brought along new health-affecting working conditions, like various immaterial stressors (5). Besides, also the employment relations changed. The erosion of the standard employment contract leads to additional stressful demands related to temporal and contractual flexibility, job insecurity, limited social protection, etc. (6;7). In addition, increased claims on personal relation skills led to occupational stress related to problematic social contacts with co-workers, clients or patients $(8,9)$.

It has been demonstrated in many studies that physical and mental distress, caused by these new working conditions, reduce general well-being and can cause health problems, ranging from mental health and physical complaints, over cardiovascular morbidity and mortality (1012). Known risk factors are high quantitative and qualitative work loads, low control over the work environment (13-17), contractual and temporal flexibility (18-21), job insecurity $(22,23)$ and unfavourable social relations at work (24-26). The main focus of this paper is on the differential distribution of a broad number of these occupational stressors: quantitative, emotional, physical and flexibility-related demands, aspects of low control over the work environment, job insecurity and negatively perceived social relationships at work. Although for each of these stressors, there is abundant evidence relating them to various outcomes of physical and psychological distress, only a very limited amount of empirical studies has specifically investigated the issue of their social distribution $(27,28)$.

Today, the most important social mechanisms that structure general life chances in the population are credentials (educational certificates or recognised experience) and social class relations (29). Credentials are mechanisms distributing the resource of valuable knowledge in society (30), while social class is the general mechanism distributing the material surplus generated by the labour process as a consequence of wage-labour (31). Attached to the so- 
cial class mechanism are relations of authority of the employers over the work of employees (31). Because they are such general social mechanisms, credentials and social class can be assumed to be critical in the distribution of occupational stressors too. In addition, social class and credentials are important underlying factors constituting occupational classifications (32), although specific task- and sector-related characteristics are usually also included as additional criteria in defining occupational categories. In this paper, a compound occupational classification, credentials and social class are the central socio-economic variables used for investigating the differential distribution of health-related occupational stressors.

Notwithstanding the lack of attention in occupational health research, the differential exposure of work-related health risks is of much importance to social epidemiology, since it provides a central pathway for explaining the contribution of "work" to the (re)production of socio-economic differences in health (33). In most studies investigating the health effects of occupational stressors, this social and occupational distribution is only obliquely addressed. With this paper we want to provide a valuable reference, empirically documenting this important, but often neglected, assumption of differential socio-economic exposure to healthrelated occupational stressors.

\section{Methods}

\section{Participants}

In this study, we use data from the Flemish Quality of Labour Monitor 2004 (Vlaamse Werkbaarheidsmonitor 2004), conducted by the Socio-Economic Council of Flanders. The Flemish region can be conceived as an example of a Post-Fordist service economy, with a high number of female and highly educated workers, predominantly employed in the service and public sectors. By using the official employee registry as the sampling frame for this survey, a representative sample of the Flemish labour market was obtained (34). Of an initial random sample of 20,000 wage-earners, 12,095 respondents returned a usable copy $(60.6 \%$ response rate). Of these, 996 individuals were excluded, because they were not working as wage-earners at the moment they filled in the questionnaire. Our analyses are based on the remaining 11,099 cases. All respondents were administered questionnaires about working conditions in a broad sense: psychosocial and physical stressors, organisational and contractual features, etc. In addition, information was gathered on health outcomes and demographic and socio-economic characteristics.

Variables included in the analyses

\section{Psychosocial item scales}

The questionnaire contains 44 individual items, each consisting of four answer categories: "always", "often", "sometimes", "never" (34). Theoretically they represent five dimensions: job autonomy (11 items), task variation (6 items), quantitative demands (11 items), emotional demands (7 items) and the relationship with direct superiors (9 items). These scales are all 
taken from the Dutch Questionnaire on the Perception and Evaluation of Labour (Vragenlijst voor de Beleving en Beoordeling van Arbeid - VBBA) (35). The VBBA-quality of labourquestionnaire has been tested frequently and the measurement scales are found to be onedimensional, reliable and valid $(35,36)$. This can be confirmed for the data analysed in this paper (37). General scale descriptives are reported in table 1. The indicators are constructed by adding up individual item scores with a range from 0 (favourable) to 3 (problematic) and placing them on a scale that is subsequently standardised to a 0 to 100 -range by using this formula: (individual score/ $\left(3^{*} \text { number of items in a scale) }\right)^{*} 100$. If missing values on a scale are randomly distributed and do not reach over $1 / 3$ of all items in the scale, mean substitution is used. If these conditions are not satisfied, the scale score of a respondent is coded as missing. The psychosocial scales are subsequently categorised into tertiles. Although relating them to the independent variables as parametric summed item scales would have been possible too, we have adopted a categorical approach, mainly for reasons of interpretability. Notwithstanding a known loss of information, a comparison of the chances of belonging to an "acute category" of the risk factors seemed to be more comprehensible than comparing abstract mean scores. Furthermore, it allows us to apply a uniform methodology over all the stressors investigated. A tertile categorisation proved to be the best compromise between sensitivity and parsimony - as appeared from additional analyses (results not shown).

\section{Physical working conditions}

The physical workload is measured by eight items: vibrations, noise, extreme temperatures, dangerous substances, dangerous situations, physically heavy work, inconvenient working postures and repetitive movements of hands and arms. Based on an unrotated Principal Components Analysis, these initial indicators - except repetitive movements - are recoded into one dimension representing the general physical workload (Table 1). For the scale construction the same procedure as described above has been used. The indicator for repetitive movements of hands and arms is used as a single item dichotomy, indicating the frequency of repetitive movements as "never or sometimes" and "often or always".

Table 1: Description of the scales - Flemish Quality of Labour Monitor, Belgium, 2004

\begin{tabular}{lccccc}
\hline & N & $\begin{array}{c}\text { Cronbach's } \\
\text { Alpha }\end{array}$ & Mean & Median & Std. Dev. \\
\hline Quantitative demands & 10,991 & .89 & 44.70 & 42.42 & 17.35 \\
Emotional demands & 10,987 & .80 & 26.78 & 23.81 & 17.07 \\
Physical demands & 10,663 & .85 & 41.29 & 35.71 & 15.64 \\
Autonomy & 10,999 & .91 & 45.86 & 45.45 & 22.38 \\
Task variation & 10,999 & .82 & 42.51 & 38.89 & 21.81 \\
Relationship with superior & 10,977 & .90 & 28.86 & 25.93 & 19.96 \\
\hline
\end{tabular}




\section{Other health-related occupational characteristics}

Types of work schedules are subdivided into two categories: "fixed day work" versus "atypical work" (a.o. night work, rotating shift systems and non-standard daytime shifts). Work schedule flexibility, conceived as the occurrence of sudden schedule changes, is subdivided into "never or sometimes" and "always or often", while overtime work is also included as a dichotomy consisting of the same categories. Next, subjective job insecurity represents the chance of becoming unemployed as "inexistent to low" versus "very high to medium high". Finally, a variable for bullying behaviour is included as a dichotomy, contrasting between "at least sometimes" and "never", within a reference period of one year.

\section{Social and occupational indicators}

The analyses are performed among women and men separately. Age is included in the models as an independent and controlling variable. The age-categories correspond to three main periods in a working career: lift-off (16-29 years), a mid-career period (30-49 years) and the end-of-career period (50 years or older). The occupational classification consists of eight categories: un-/semi-schooled workers, schooled manual workers, educational professionals, health care professionals, other professionals, middle managers, higher managers and nonmanual routine workers, which is the reference category. The dimension of credentialed skills is a constructed indicator, inspired by Parkin's notion of credentialism (38). Respondents with no or lower secondary education and those who combine higher secondary education with un-/semi-schooled manual, non-manual routine, educational or healthcare occupations are classified as lower skilled. Schooled manual workers, professionals and managerial employees with higher secondary educational attainment, as well as manual, non-manual routine, educational and healthcare workers with higher non-university educational attainment are categorised into the semi-skilled-category. Finally, professionals and managerial employees with non-university higher education and all respondents with a university degree are classified as experts. Class relations are defined by real economic ownership and its prerogative of strategic policy-making and surveillance authority over employees (29). In this regard, Clement and Myles (31) suggest to make a distinction between higher managers, who combine strategic decision-making and surveillance authorities and supervisors, having no strategic decision-making authority, but only delegated surveillance authority. In addition, there is the category of employees, who lack both properties. The indicator resulting from this distinction is constructed by cross-classifying the occupational qualification of "higher manager" with the property of having authority over other employees.

\section{Analytical procedure}

The socio-economic distribution of the stressors is assessed through a number of standard logistic regression analyses. Age-controlled analyses are performed in women and men separately. The individual parameter effects are reported as odds ratios with $95 \%$ confidence intervals, indicating the extent of difference in exposure compared to a reference category (Tables 3-5). In addition, Wald statistics and their related p-values give an indication of the 
significance of the overall effects of the independent variables. It should moreover be noticed that the magnitude of the odds ratio of a certain category of an independent variable in men may not be compared to the same category in women (and vice versa).

Table 2: Descriptives for the categorical variables - Flemish Quality of Labour Monitor, Belgium, 2004

\begin{tabular}{|c|c|c|c|c|c|c|c|}
\hline & $\mathbf{N}$ & \multicolumn{2}{|c|}{$\%$} & & $\mathbf{N}$ & \multicolumn{2}{|c|}{$\%$} \\
\hline Gender & & \multicolumn{2}{|c|}{ Overall } & Age & & \multicolumn{2}{|c|}{ Overall } \\
\hline Women & 4,902 & \multicolumn{2}{|c|}{47.5} & $16-29$ years & 2,106 & \multicolumn{2}{|c|}{20.5} \\
\hline \multirow[t]{3}{*}{ Men } & 5,409 & \multicolumn{2}{|c|}{52.5} & $30-49$ years & 6,378 & \multicolumn{2}{|c|}{61.9} \\
\hline & & & & 50 years and older & 1,810 & \multicolumn{2}{|c|}{17.6} \\
\hline & & Men & Women & & & Men & Women \\
\hline Quantitative demands & & & & Low autonomy & & & \\
\hline Highest tertile & 3,447 & 32.3 & 30.0 & Highest tertile & 3,546 & 32.3 & 32.1 \\
\hline Lowest and middle tertile & 7,544 & 67.7 & $70.0^{*}$ & Lowest and middle tertile & 7,453 & 67.7 & 67.9 \\
\hline Emotional demands & & & & Low task variation & & & \\
\hline Highest tertile & 3,162 & 26.8 & 30.9 & Highest tertile & 3,510 & 28.1 & 36.2 \\
\hline Lowest and middle tertile & 7,825 & 73.2 & $69.1^{* \star *}$ & Lowest and middle tertile & 7,489 & 71.9 & $63.8^{* \star *}$ \\
\hline Physical demands & & & & Low support & & & \\
\hline Highest tertile & 3,650 & 46.9 & 20.1 & Highest tertile & 3,393 & 33.2 & 28.3 \\
\hline Lowest and middle tertile & 7,013 & 53.1 & $79.9^{\star \star \star}$ & Lowest and middle tertile & 7,584 & 66.8 & $71.7^{* * *}$ \\
\hline Repetitive movements & & & & Overtime work & & & \\
\hline Always-often & 3,750 & 34.2 & 36.6 & Always-often & 3,472 & 35.3 & 29.6 \\
\hline Never-sometimes & 6,879 & 65.8 & $34.2^{*}$ & Never-sometimes & 7,205 & 64.7 & $70.4^{* * *}$ \\
\hline Type of work schedule & & & & Schedule changes & & & \\
\hline Atypical schedule & 2,654 & 25.6 & 23.9 & Always-often & 1,560 & 17.8 & 11.4 \\
\hline Fixed daytime work & 7,956 & 74.4 & $76.1^{*}$ & Never-sometimes & 9,122 & 82.2 & $88.6^{* \star *}$ \\
\hline Bullying behaviour & & & & Job insecurity & & & \\
\hline Sometimes-always & 1,527 & 14.4 & 14.3 & High & 2,385 & 23.6 & 20.9 \\
\hline No & 9,108 & 85.6 & 85.7 & Low & 8,316 & 76.4 & $79.1^{* *}$ \\
\hline Occupational categories & & & & Skill & & & \\
\hline Un-/semi-schooled man. & 1,484 & 15.3 & 13.3 & Lower skilled & 4,666 & 45.1 & 46.2 \\
\hline Schooled manual & 2,126 & 32.5 & 7.5 & Semi-skilled & 3,582 & 33.1 & 37.1 \\
\hline Educational prof. & 880 & 4.5 & 13.1 & Expert & 1,977 & 21.7 & $16.7^{* * *}$ \\
\hline Healthcare prof. & 801 & 1.6 & 14.5 & Social class & & & \\
\hline Other prof. & 773 & 8.5 & 6.3 & Workers & 8,311 & 69.1 & 87.8 \\
\hline Middle managers & 760 & 9.6 & 4.5 & Supervisors & 1,890 & 24.0 & 10.2 \\
\hline Higher managers & 490 & 7.1 & 2.0 & Higher management & 490 & 6.9 & $1.9^{* \star \star}$ \\
\hline Non-manual routine & 2,995 & 20.8 & $38.7^{\star \star \star}$ & & & & \\
\hline
\end{tabular}

Significance levels Chi $^{2}$ statistics: ${ }^{*} p<.05 ;{ }^{* *} p<.01 ;{ }^{* * *} p<.001$ 
Table 3: Distribution of highest tertiles of quantitative, emotional and physical demands over socio-economic categories - overall and gender specific analyses (ORs -

95\% Cls) - Flemish Quality of Labour Monitor, Belgium, 2004

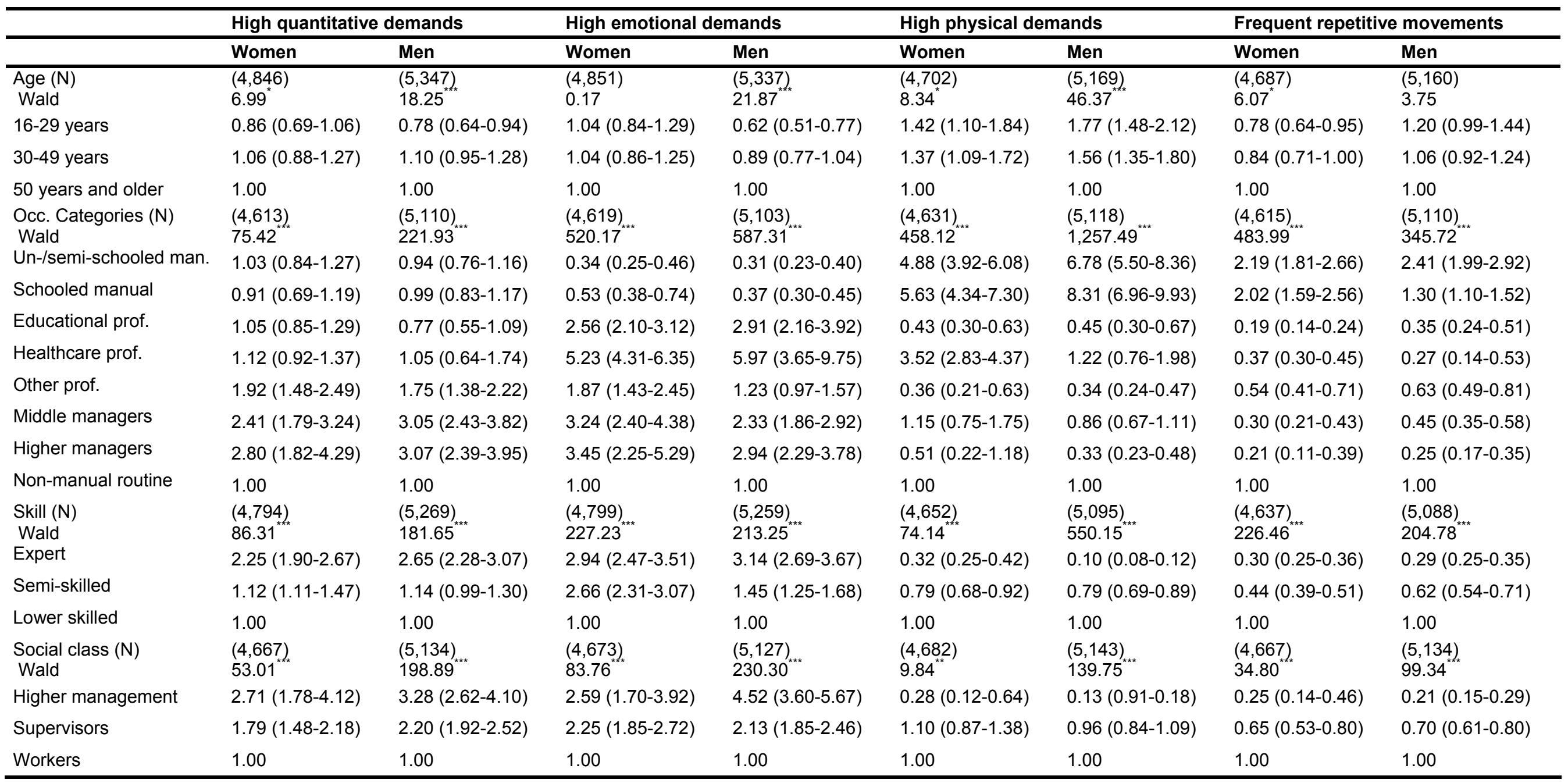

Gender specific models: all effects controlled for age; Significance of the Wald statistics: ${ }^{*} p<.05 ;{ }^{* *} p<.01 ;{ }^{* \star *} p<.001$ 
Table 4: Distribution of highest tertiles of repetitive movements, atypical work schedules and overtime work over socio-economic categories - overall and gender specific analyses (ORs - 95\% Cls) - Flemish Quality of Labour Monitor, Belgium, 2004

\begin{tabular}{|c|c|c|c|c|c|c|c|c|}
\hline & \multicolumn{2}{|c|}{ Atypical work schedules } & \multicolumn{2}{|c|}{ Frequent overtime work } & \multicolumn{2}{|c|}{ Sudden schedule changes } & \multicolumn{2}{|l|}{ Low autonomy } \\
\hline & Women & Men & Women & Men & Women & Men & Women & Men \\
\hline $\begin{array}{l}\text { Age }(\mathrm{N}) \\
\text { Wald }\end{array}$ & $\begin{array}{l}(4,713) \\
8.82^{*}\end{array}$ & $\begin{array}{l}(5,187) \\
27.05^{\star * *}\end{array}$ & $\begin{array}{l}(4,704) \\
17.71^{* *}\end{array}$ & $\begin{array}{l}(5,178) \\
32.25^{* * *}\end{array}$ & $\begin{array}{l}(4,717) \\
24.34^{* *}\end{array}$ & $\begin{array}{l}(5,174) \\
12.71^{* \pi}\end{array}$ & $\begin{array}{l}(4,852) \\
2.62\end{array}$ & $\begin{array}{l}(5,346) \\
13.95^{* *}\end{array}$ \\
\hline $16-29$ years & $1.40(1.11-1.77)$ & $1.75(1.42-2.17)$ & $1.60(1.28-2.00)$ & $1.63(1.35-1.97)$ & $2.17(1.55-3.03)$ & $1.45(1.14-1.84)$ & $0.85(0.69-1.04)$ & $1.43(1.19-1.73)$ \\
\hline $30-49$ years & $1.18(0.96-1.45)$ & $1.63(1.37-1.94)$ & $1.34(1.10-1.63)$ & $1.50(1.29-1.75)$ & $1.49(1.09-2.03)$ & $1.41(1.16-1.71)$ & $0.93(0.77-1.11)$ & $1.05(0.90-1.23)$ \\
\hline 50 years and older & 1.00 & 1.00 & 1.00 & 1.00 & 1.00 & 1.00 & 1.00 & 1.00 \\
\hline $\begin{array}{l}\text { Occ. Categories }(\mathrm{N}) \\
\text { Wald }\end{array}$ & $\begin{array}{l}(4,644)_{* \star *} \\
732.66\end{array}$ & $\begin{array}{l}(5,142)_{* * *} \\
367.82\end{array}$ & $\begin{array}{l}(4,630)_{* * *} \\
448.00^{*}\end{array}$ & $\begin{array}{l}(5,129)_{* \star *} \\
697.79\end{array}$ & $\begin{array}{l}(4,643)_{* * *} \\
141.54\end{array}$ & $\begin{array}{l}(5,125)_{* \star *} \\
320.67^{*}\end{array}$ & $\begin{array}{l}(4,622)_{* \star *} \\
226.06\end{array}$ & $\begin{array}{l}(5,111)_{* \star *} \\
454.68\end{array}$ \\
\hline Un-/semi-schooled man. & $3.86(3.11-4.79)$ & $2.40(1.96-2.95)$ & $0.50(0.38-0.65)$ & $0.63(0.50-0.78)$ & $1.23(0.88-1.72)$ & $0.85(0.65-1.12)$ & $3.31(1.91-2.80)$ & $2.82(2.32-3.42)$ \\
\hline Schooled manual & $3.13(2.40-4.07)$ & $1.66(1.39-1.98)$ & $0.61(0.44-0.84)$ & $0.70(0.59-0.84)$ & $1.35(0.91-2.00)$ & $0.82(0.65-1.03)$ & $2.04(1.60-2.58)$ & $1.53(1.30-1.80)$ \\
\hline Educational prof. & $0.42(0.29-0.60)$ & $0.20(0.11-3.37)$ & $3.71(3.04-4.52)$ & $1.92(1.42-2.60)$ & $0.85(0.59-1.23)$ & $0.45(0.26-0.78)$ & $0.81(0.65-1.00)$ & $0.60(0.42-0.84)$ \\
\hline Healthcare prof. & $10.33(8.38-12.72)$ & $7.86(4.81-12.86)$ & $1.65(1.35-2.01)$ & $1.40(0.88-2.23)$ & $3.02(2.33-3.92)$ & $2.17(1.30-3.63)$ & $1.21(1.00-1.46)$ & $1.19(0.74-1.91)$ \\
\hline Other prof. & $0.24(0.13-0.45)$ & $0.27(0.18-0.40)$ & $3.12(2.41-4.04)$ & $2.70(2.14-3.42)$ & $2.26(1.57-3.26)$ & $1.90(1.43-2.53)$ & $0.40(0.28-0.56)$ & $0.28(0.20-0.39)$ \\
\hline Middle managers & $0.50(0.29-0.86)$ & $0.61(0.46-0.82)$ & $4.45(3.29-6.00)$ & $5.34(4.22-6.76)$ & $3.75(2.58-5.47)$ & $3.09(2.38-4.00)$ & $0.24(0.15-0.38)$ & $0.23(0.16-0.32)$ \\
\hline Higher managers & $0.22(0.07-0.69)$ & $0.17(0.10-0.28)$ & $16.69(9.58-29.05)$ & $12.36(9.14-16.72)$ & $5.31(3.25-8.69)$ & $5.44(4.12-7.18)$ & $0.08(0.02-0.24)$ & $0.04(0.02-0.09)$ \\
\hline Non-manual routine & 1.00 & 1.00 & 1.00 & 1.00 & 1.00 & 1.00 & 1.00 & 1.00 \\
\hline $\begin{array}{l}\text { Skill (N) } \\
\text { Wald }\end{array}$ & $\begin{array}{l}(4,664)_{* \star *} \\
125.80^{*}\end{array}$ & $\begin{array}{l}(5,112)_{* * \star} \\
233.12^{*}\end{array}$ & $\begin{array}{l}(4,653)_{* * *} \\
331.19^{*}\end{array}$ & $\begin{array}{l}(5,104)^{* \star *} \\
555.82\end{array}$ & $\begin{array}{l}(4,666) \\
49.73^{\star \star}\end{array}$ & $\begin{array}{l}(5,099)_{* \star \star} \\
181.07^{*}\end{array}$ & $\begin{array}{l}(4,801)^{* \star *} \\
157.13^{*}\end{array}$ & $\begin{array}{l}(5,270)_{* \star \star} \\
352.72^{*}\end{array}$ \\
\hline Expert & $0.20(0.15-0.26)$ & $0.15(0.12-0.19)$ & $5.00(4.18-5.99)$ & $6.41(5.48-7.50)$ & $2.34(1.85-2.97)$ & $3.02(2.54-3.60)$ & $0.25(0.20-0.31)$ & $0.14(0.11-0.17)$ \\
\hline Semi-skilled & $0.92(0.80-1.06)$ & $0.73(0.64-0.84)$ & $2.68(2.31-3.12)$ & $1.52(1.32-1.75)$ & $1.36(1.10-1.68)$ & $1.11(0.93-1.33)$ & $0.70(0.61-0.80)$ & $0.56(0.49-0.63)$ \\
\hline Lower skilled & 1.00 & 1.00 & 1.00 & 1.00 & 1.00 & 1.00 & 1.00 & 1.00 \\
\hline $\begin{array}{l}\text { Social class }(\mathrm{N}) \\
\text { Wald }\end{array}$ & $\begin{array}{l}(4,696)^{*} \\
16.94^{*}\end{array}$ & $\begin{array}{l}(5,165)_{\star *} \\
73.76^{*}\end{array}$ & $\begin{array}{l}(4,683)_{* * *} \\
183.38^{*}\end{array}$ & $\begin{array}{l}(5,153)_{* * *} \\
458.29^{2}\end{array}$ & $\begin{array}{l}(4,696) \\
63.85^{* * t}\end{array}$ & $\begin{array}{l}(5,150)_{\star * *} \\
256.29\end{array}$ & $\begin{array}{l}(4,675)^{*} \\
85.67^{* *}\end{array}$ & $\begin{array}{l}(5,134)_{* * *} \\
212.44^{-}\end{array}$ \\
\hline Higher management & $0.11(0.03-0.34)$ & $0.12(0.07-0.21)$ & $13.49(7.81-23.32)$ & $13.52(10.23-17.87)$ & $3.88(2.43-6.21)$ & $6.16(4.85-7.82)$ & $0.06(0.20-0.20)$ & $0.03(0.01-0.06)$ \\
\hline Supervisors & $0.82(0.65-1.04)$ & $0.76(0.66-0.89)$ & $2.74(2.26-3.32)$ & $2.65(2.31-3.03)$ & $2.19(1.71-2.81)$ & $2.23(1.89-2.63)$ & $0.35(0.27-0.46)$ & $0.38(0.33-0.45)$ \\
\hline Workers & & 1.00 & 1.00 & 1.00 & 1.00 & 1.00 & 1.00 & 1.00 \\
\hline
\end{tabular}

Gender specific models: all effects controlled for age.; Significance of the Wald statistics: ${ }^{*} p<.05 ;{ }^{* *} p<.01 ;{ }^{* * *} p<.001$ 
Table 5: Distribution of highest tertiles of sudden schedule changes, low autonomy and low task variation over socio-economic categories - overall and gender specific analyses (ORs - 95\% Cls) - Flemish Quality of Labour Monitor, Belgium, 2004

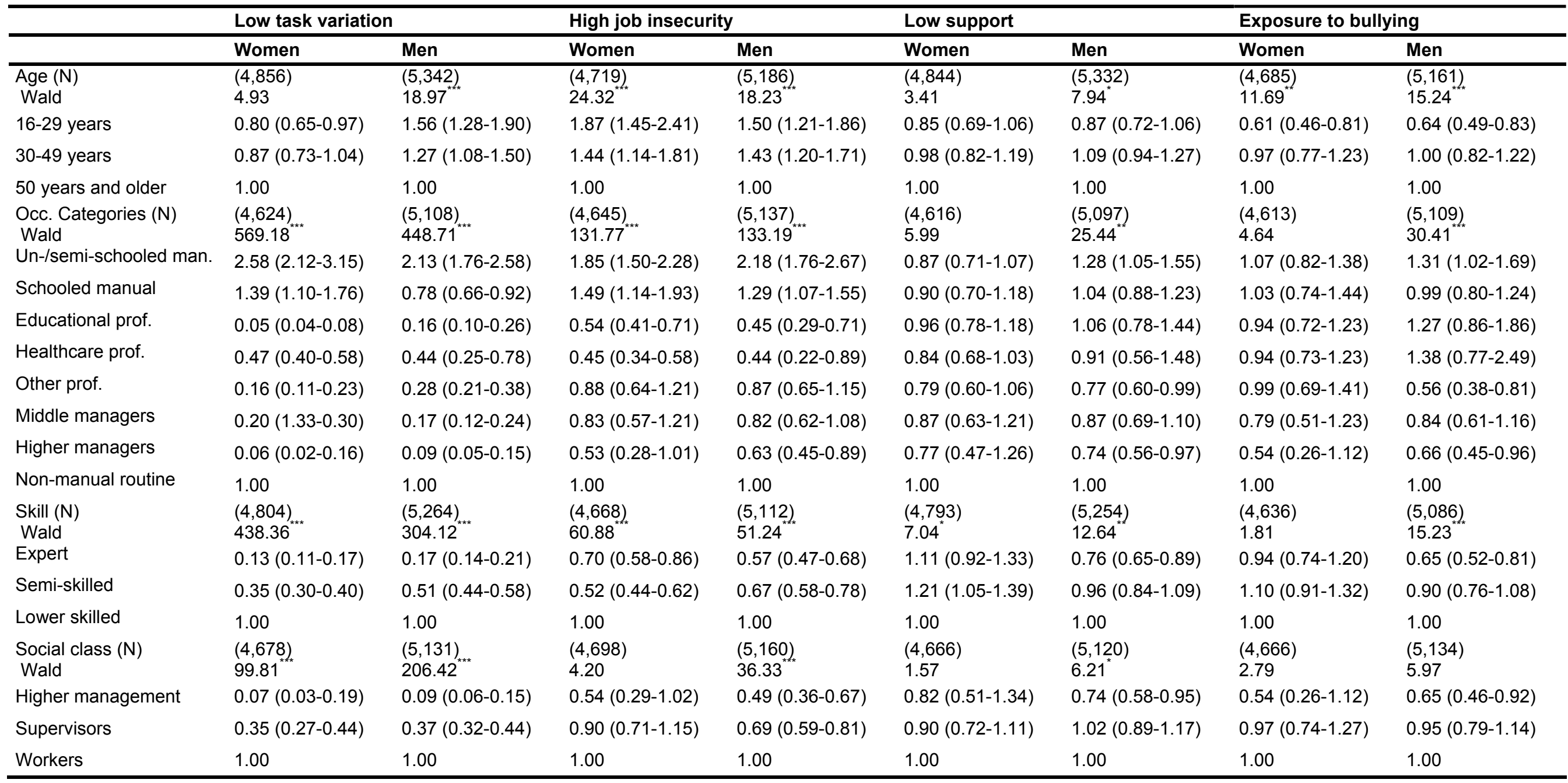

Gender specific models: all effects controlled for age; Significance of the Wald statistics: ${ }^{*} p<.05 ;{ }^{* *} p<.01 ;{ }^{* * *} p<.001$ 


\section{Results}

\section{Descriptive results}

In table 2 the overall absolute numbers of the categories of the dependent and independent variables are shown, as well as their gender-specific prevalence. When looking at the occupational stressors that are used as outcome variables in the further analyses, significant gender differences in exposure can be seen for most of them, except for low autonomy and bullying behaviour. Men are more exposed to high quantitative and physical demands of work, atypical work schedules, low social support, overtime work, frequent schedule changes and high job insecurity. Women, on the other hand, find themselves more often in a situation of high emotional demands, frequent repetitive movements and low task variation. Also significant gender differences exist for the independent socio-economic indicators. Women are overrepresented as healthcare and educational professionals and as non-manual routine workers. In addition, there is a lower proportion of women in expert level, supervising and higher managerial positions.

The age-corrected socio-economic distribution of the occupational stressors

In tables 3 to 5 the gender-specific distribution of the occupational stressors according to age, occupation, credentialed skills and social class is reported. All the reported results are controlled for age. The reference categories of the independent variables are employees of 50 years and older, non-manual routine occupations, lower skilled and workers without authority.

Age

Younger employees have a higher chance of being exposed to high physical demands, frequent overtime work, schedule changes and high job insecurity. In addition, also atypical work schedules are more prevalent in female employees belonging to the youngest age category, while for male workers, the oldest age category shows a lower prevalence of atypical work schedules. Low task variation and low autonomy are more frequently reported in the youngest male age category, compared to the oldest. For women, however, there are no significant age differences in (low) task variation and autonomy. High quantitative demands and exposure to bullying are significantly less prevalent among the youngest respondents. Furthermore, high emotional demands in men, and frequent repetitive movements in women are slightly more prevalent in the oldest age group. Low social support shows no clear agevariation.

\section{Occupational categories}

First, there is a series of occupational risk factors that tend to be more prevalent in manual occupations. Unsurprisingly, manual occupations have a markedly higher exposure to physical demands and frequent repetitive movements, compared to non-manual occupations. This pattern can be seen in both women and men, although it is somewhat stronger in men. Fe- 
male healthcare occupations also have elevated odds for exposure to high physical working conditions. Atypical work schedules are more common in manual occupations and healthcare professionals. Interestingly, the contrast in the prevalence of atypical schedules between manual and healthcare occupations on the one hand, and non-manual on the other hand, is bigger in women than in men. High job insecurity is another risk factor that is typical for manual occupations, while healthcare (and educational) professionals are the most advantaged categories with regard to this outcome. Finally, also the conceptually and empirically related occupational stressors of low autonomy and low task variation are more apparent in (lower skilled) manual occupations. Specifically among women steep differences with non-manual workers are seen. Furthermore, the reference category of non-manual routine employees also shows a relatively high prevalence of low autonomy and task variation in both gender groups. In general terms, professional and managerial employees seldom report problems with the above discussed list of risk factors. However, in these occupational categories, a number of other potentially health-damaging occupational stressors are more prevalent. Compared with routine non-manual workers, professionals, middle managers and higher managers have more than double the odds of being exposed to high quantitative demands. Very much related to quantitative demands are overtime work and sudden schedule changes. Overtime work is a typical characteristic of professional and managerial occupations, with both male and female higher managers having odds of more than 10 times higher than the reference category. Also female educational professionals have higher chances for experiencing overtime work. Largely the same picture holds for sudden schedule changes in the case of professionals and managerial occupations. Elevated odds ratios for this outcome are also seen in healthcare professionals. Finally, also the more "qualitative" indicator of emotional demands, shows more or less the same occupational pattern. Here, however the most important risk category is healthcare professionals. Two work-related stressors are only very modestly related with occupational categories: social support and exposure to bullying behaviour. With regard to social support it is shown that managerial jobs generally have slightly less problems, while male un- or semi-schooled manual workers are facing a significantly higher prevalence of exposure. Nearly exactly the same pattern holds for exposure to bullying behaviour.

The pattern that is seen for the occupational classification is also reflected in its main constituting factors, credentialed skills and social class. As concerns credentialed skills, expertlevel workers have the highest prevalence of quantitative demands, overtime work, frequent schedule changes and emotional demands. On the other hand, exposure to high physical demands and frequent repetitive movements tends to decrease with higher skill levels. The same holds for atypical work schedules, low autonomy and task variation, as well as job insecurity and bullying behaviour. Interestingly, the association - although it is rather weak between low support and credentialed skills is different for men and women: while higher (semi-skilled) female employees tend to have a slightly higher prevalence of low support, compared to lower skilled, this pattern is opposite for male employees. Finally, in general, for each of these stressors semi-skilled workers take an intermediate position. The indicator of 
social class shows members of the higher management to be less exposed to physical demands, repetitive movements, atypical work schedules, low autonomy, low task variation and bullying. On the other hand, the reference category of workers without any authority over other workers is less likely to experience high quantitative or emotional demands, frequent overtime work or sudden schedule changes. Contrary to the semi-skilled workers, the category of supervisors in this social class indicator is not always taking an in-between position between workers and higher managers. In the case of physical demands, atypical work schedules, job insecurity, low support and exposure to bullying behaviour, the position of supervisors inclines more towards that of the (less advantageous) category of workers. In general, the relative differences between the class-categories are very much the same in men and in women. The only exception to this pattern is seen for the exposure to frequent schedule changes: the odds ratio (compared to workers) of higher managerial employees is far more elevated in men than in women.

\section{Discussion}

This study provides a detailed description of the differential distribution of health-related occupational stressors according to gender, age, occupational categories, skill levels and social class. In the international empirical occupational health literature, reliable data on the socioeconomic distribution of such a large amount of occupational stressors is scarce - especially within a large sample, representative for the entire wage-earning population in a region. Only a limited number of studies investigated the demographic and socio-economic distribution of common psychosocial stressors, such as immaterial demands, control over the work environment or support, as well as general physical demands $(27,28,39-41)$. The distribution of risk factors such as emotional demands, features of precarious employment, bullying, etc. has remained nearly unaddressed (for one exception, see: Letourneux (42). As a consequence, this paper provides a valuable reference in documenting the often assumed pathway informing work-related socio-economic inequalities in health.

In summary, it may be concluded that women report a clearly higher prevalence of high emotional demands and low task variation, which is in line with findings from previous research (28,39-41). In men, by contrast, high physical demands, overtime work and sudden schedule changes are more prevalent. Previous research on gender-associations with work demands is not conclusive. Some authors have found higher demands in men $(43,44)$, but also nonsignificant gender differences (41), and a higher prevalence of time pressure and emotional demands are reported for women (39). Finally, the gender-association with low support from direct superiors is limited - which is in line with previous research $(39,45)$.

The youngest age category reports higher odds for high physical demands, atypical schedules, frequent overtime work, schedule changes and high job insecurity, as well as low autonomy and task variation - the latter however only in men. High emotional demands and - to a lesser extent - exposure to bullying are more common in the older age category. In contrast to our findings, in the scientific literature, low control (autonomy and task variation) is 
frequently found to be more prevalent in the older age categories $(28,40,41)$. On the other hand, our findings of job demands - and specifically physical demands - being more prevalent in younger ages are in line with previous findings $(27,28,46)$.

Manual occupational categories are more frequently exposed to high physical demands, frequent repetitive movements, atypical work schedules, low autonomy and task variation and high job insecurity. The "higher-end" occupations of managerial and professional employees are more often exposed to high quantitative and emotional demands, frequent overtime work and schedule changes. A specific position is taken by educational and health care professionals - which are typical examples of emotional labourers (47). Emotional labourers are more prone to stressors related to interpersonal conflicts or touching interpersonal contacts (9). This situation is reflected in the elevated exposure to high emotional demands. Moreover, frequent overtime work in educational professionals and atypical work schedules and high physical demands in healthcare professionals reflect the specificity of work organisation in these sectors. On the other hand, these occupational categories are less confronted with job insecurity, a finding that can be explained by their predominant public sector employment. The stressors related to social interactions show no clear distribution - something that is also seen in previous research $(39,45)$. Problems of low control in manual (and other routine) occupations have been reported frequently before $(46,48)$ - just as the experience of high immaterial demands in professional and managerial occupations $(27,28,46)$. When considering the indicators of class and skill, high physical demands, atypical schedules, low control over the work environment and high job insecurity are more common in manual, unskilled and subordinate workers. On the other hand, a cluster of high quantitative and emotional demands, as well as schedule-unpredictability can be seen in higher-skilled and managerial employees.

Although, in general terms, the patterns of distribution in both sexes are fairly similar, some gender-specific patterns exist. Exceptions are the smaller occupational variation in physical demands within female workers and the lower prevalence of schedule unpredictability among female managerial workers. The latter may be related to generally higher domestic demands which need to be reconciliated with professional demands (49). In addition, some very specific gendered patterns are seen for quantitative demands, repetitive movements, atypical work schedules, overtime work and low autonomy.

In interpreting these results, some limitations have to be kept in mind. First of all, a small age-selection effect in these data can be assumed, related to the "selecting-out" of specific types of older employees - for example, those working in the most adverse conditions. This could not be controlled formally; however, the non-response analysis showed that the number of people that stopped working between the time of sampling and their participation in the survey was highest in the oldest age categories (34). Another limitation is the cross-sectional nature of the data. As a result, causality assumptions cannot be tested empirically. Of course, some causal orders are clear from a theoretical point of view, but in some instances the direction of causality can be discussed. An associated problem is the lack of 'exposure 
time estimates'. Possibly the time of exposure to unfavourable occupational characteristics is also socially distributed.

\section{Conclusions}

In sum, this study suggests that the distribution of health-related occupational stressors within the Flemish wage-earning population is clustered and associated with socio-economic and occupational positions. On the one hand, high physical demands, atypical schedules, low control over the work environment and high job insecurity are more common in manual, unskilled and subordinate workers. On the other hand, a cluster of high quantitative and emotional demands, as well as schedule unpredictability can be seen in higher-skilled, professional and managerial employees. This finding - at least in terms of health-affecting working conditions - contradicts dual labour market theories (50), assuming the division of contemporary Post-Fordist labour into "good jobs" and "bad jobs". Similar conclusions are also made by De Beer (51), finding that the hierarchical segmentation of the labour market into good jobs and bad jobs can only be partly supported, since a number of distinct stressors, like different psychological work demands, are more prevalent in the higher-end occupations. Our findings are of relevance to occupational health research as well as research on socio-economic health inequalities.

\section{Acknowledgements}

This research is facilitated by the research grant "OZR-1005", that is assigned to the first author by the Research Council of the Vrije Universiteit Brussel. For this study we use the "Flemish Quality of Labour Monitor, 2004", originated and owned by the Socio-Economic Council of Flanders. The content of this paper is at the full responsibility of the authors. The authors like to thank the owners of the database for giving permission to use their data for the purpose of scientific research.

\section{References}

1. Watson TJ. Sociology, Work and Industry. 4th ed. London: Routledge, 2003

2. Lipietz A. The fortunes and misfortunes of the central regime of accumulation: fordism. In: Lipietz A, editor. Mirages and Miracles. The Crisis of Global Fordism. Verso, 1987: 29-46

3. Bihr A. Du "grand soir" a "l'alternative". The European labour movement in crisis. (Du "grand soir" a "l'alternative": Le mouvement ouvrier europeen en crise). Paris: Editions Ouvrières, 1991

4. Ackerman F, Goodwin NR, Dougherty L, Gallagher K. The Changing Nature of Work. Washington: Island Press, 1998

5. De Jonge J, Kompier MAJ. A critical examination of the demand-control-support model from a work psychological perspective. International Journal of Stress Management 1997; 4:235-58

6. Cooper CL. The changing psychological contract at work. Occup Environ Med 2002; 59(6):355

7. Benach J, Muntaner C. Precarious employment and health: developing a research agenda. J Epidemiol Community Health 2007; 61(4):276-7

8. Fineman S. Emotion in Organizations. Newbury Park: Sage, 1993 
9. Hochschild AR. The managed heart. Berkeley: University of California Press, 1983

10. Bongers PM, Dewinter CR, Kompier MAJ, Hildebrandt VH. Psychosocial Factors at Work and Musculoskeletal Disease. Scand J Work Environ Health 1993; 19(5):297-312

11. Tennant C. Work-related stress and depressive disorders. J Psychosom Res 2001; 51(5):697-704

12. Tennant C. Work stress and coronary heart disease. J Cardiovasc Risk 2000; 7(4):273-6

13. Godin I, Kittel F. Differential economic stability and psychosocial stress at work: associations with psychosomatic complaints and absenteeism. Soc Sci Med 2004; 58(8):1543-53

14. Karasek R, Kawakami N, Brisson C, Houtman ILD, Bongers PM, Amick B. The job content questionnaire (JCQ): An instrument for internationally comparative assessments of psychosocial job characteristics. J Occup Health Psychol 1998; 3(4):322-55

15. Siegrist J. Psychosocial work environment and health: new evidence. J Epidemiol Community Health 2004; 58(11):888

16. Vanroelen C, Levecque K, Louckx F. Psychosocial working conditions and self-reported health in a representative sample of wage-earners: a test of the different hypotheses of the Demand-Control-SupportModel. Int Arch Occup Environ Health 2009; 82(3):329-42

17. Vanroelen C, Levecque K, Moors G, Gadeyne S, Louckx F. The structuring of occupational stressors in a Post-Fordist work environment. Moving beyond traditional accounts of demand, control and support. Soc Sci Med 2009; 68(6):1082-90

18. Akerboom S, Maes S. Beyond demand and control: The contribution of organizational risk factors in assessing the psychological well-being of health care employees. Work Stress 2006; 20(1):21-36

19. Costa G, Gadbois C, Jansen B, Knauth P, Léonard R. Shiftwork and Health. 1. 2000. Dublin, European Foundation for the Improvement of Living and Working Conditions. Best. European Studies on Time

20. Costa G, D'errico A. Inequalities in health: do occupational risks matter? Eur J Public Health 2006; 16(4):340

21. Muecke S. Effects of rotating night shifts: literature review. J Adv Nurs 2005; 50(4):433-9

22. Ferrie JE. Health consequences of job insecurity. In: Ferrie JE, Marmot MG, Griffiths J, Ziglio E, editors. Labour market changes and job insecurity. A challange for social welfare and health promotion. Copenhagen: World Health Organization. Regional Office for Europe., 1999: 59-99

23. Ferrie JE, Shipley MJ, Newman K, Stansfeld SA, Marmot M. Self-reported job insecurity and health in the Whitehall II study: potential explanations of the relationship. Soc Sci Med 2005; 60(7):1593-602

24. Agervold M, Mikkelsen EG. Relationships between bullying, psychosocial work environment and individual stress reactions. Work Stress 2004; 18(4):336-51

25. Bültmann U, Kant IJ, Schroer CAP, KasI SV. The relationship between psychosocial work characteristics and fatigue and psychological distress. Int Arch Occup Environ Health 2002; 75(4):259-66

26. Van Der Doef M, Maes S, Diekstra R. An examination of the job demand-control-support model with various occupational strain indicators. Anxiety Stress Coping 2000; 13(2):165-85

27. Kristensen TS, Borg V, Hannerz H. Socioeconomic status and psychosocial work environment: results from a Danish national study. Scand J Public Health 2002; 30(3):41-8

28. Niezborala M, Marquie JC, Baracat B, Esquirol Y, Soulat JM. Job stress and occupational status in a French cohort. Rev Epidemiol Sante Publique 2003; 51(6):607-16

29. Wright EO. The shadow of exploitation in Weber's class analysis. Am Sociol Rev 2002; 67(6):832-53

30. Bourdieu P. The forms of capital. In: Richardson JG, editor. The handbook of theory and research for the sociology of education. New York: Greenwood Press, 1986: 241-58

31. Clement W, Myles J. Relations of ruling. Class and gender in postindustrial societies. Québec: McGillQueens University Press, 1994

32. Krieger N. A glossary for social epidemiology. J Epidemiol Community Health 2001; 55(10):693-700 
33. Siegrist J, Theorell T. Socio-economic position and health. The role of work and employment. In: Siegrist J, Marmot M, editors. Social Inequalities in Health. New Evidence and Policy Implications. Oxford: Oxford University Press, 2006: 73-100

34. Bourdeaud'hui R, Janssens J, Vanderhaeghe S. Information file of the Flemish Quality of Labour Monitor. Indicators for the quality of labour of the Flemish labour market 2004 (Informatiedossier Vlaamse werkbaarheidsmonitor. Indicatoren voor de kwalitieit van de arbeid op de Vlaamse arbeidsmarkt 2004). 1-230. 2004. Brussels, STV-Innovatie \& Arbeid

35. Van Veldhoven M, Meijman TF, Broersen JPJ, Fortuin RJ. Manual VBBA (Handleiding VBBA). 2002. SKB Vragenlijst services

36. Evers A, Van Vliet-Mulder JC, Groot CJ. Documentation of tests and test research in The Netherlands. Test research (Documentatie van tests en testresearch in Nederland. Testresearch). 1370-3. 2000. Assen, Van Gorcum \& Comp B.V.

37. Vanroelen C. Work-Related Health Complaints in a Post-Fordist Labour Force. A sociology of workrelated socio-economic health inequalities. Brussels: VUB Press, 2009

38. Parkin F. Marxism and class theory: a bourgeois critique. New York: Columbia University Press, 1979

39. Aittomaki A, Lahelma E, Roos E. Work conditions and socioeconomic inequalities in work ability. Scand J Work Environ Health 2003; 29(2):159-65

40. Pedersen HS, Mahler S, Hansen CB. Danish work environment cohort study. Trends in a 10-year perspective Job-related differences Sector-related differences Gender-related differences About the study Commentary List of publications linked to the survey. 2005. Dublin, European Foundation for the Improvement of Living and Working Conditions

41. De Smet P, Sans S, Dramaix M, Boulenguez C, De Backer G, Ferrario M et al. Gender and regional differences in perceived job stress across Europe. Eur J Public Health 2005; 15(5):536-45

42. Letourneux V. Precarious employment and working conditions in the European Union. 1998. Luxembourg, Office for official publication of the European communities. European foundation for the improvement of living and working conditions

43. Tsutsumi A, Kayaba K, Theorell T, Siegrist J. Association between job stress and depression among Japanese employees threatened by job loss in a comparison between two complementary job-stress models. Scand J Work Environ Health 2001; 27(2):146-53

44. Hunt K, Annandale E. Just the Job - Is the Relationship Between Health and Domestic and Paid Work Gender-Specific. Sociol Health IIIn 1993; 15(5):632-64

45. Melchior M, Krieger N, Kawachi I, Berkman LF, Niedhammer I, Goldberg M. Work factors and occupational class disparities in sickness absence: Findings from the GAZEL cohort study. Am J Public Health 2005; 95(7):1206-12

46. Bosma H, Peter R, Siegrist J, Marmot M. Two alternative job stress models and the risk of coronary heart disease. Am J Public Health 1998; 88(1):68-74

47. Hardt M. Affective Labour. Boundary 2 1999; 26(2):89-100

48. Marmot M, Bosma H, Hemingway H, Brunner E, Stansfeld S. Contribution of job control to social gradient in coronary heart disease - Reply. Lancet 1997; 350(9088):1405

49. Eby LT, Casper WJ, Lockwood A, Bordeaux C, Brinley A. Work and family research in IO/OB: Content analysis and review of the literature (1980-2002). J Vocat Behav 2005; 66(1):124-97

50. Piore M. Labor Market Segmentation: To What Paradigm Does It Belong? American Economic Review Papers and Proceedings 1983; 73:249-53

51. De Beer PT. About work in the post-industrial society. (Over werken in de postindustriële samenleving). 2002. Den Haag, Sociaal en Cultureel Planbureau 